\title{
Robert Kennedy and the Cuban Missile Crisis: A Reassertion of Robert Kennedy's Role as the President's 'Indispensable Partner' in the Successful Resolution of the Crisis
}

\section{Abstract}

In commemoration of the 50th anniversary of his death, this article examines the role Attorney General Robert F. Kennedy (RFK) played in the successful resolution of the Cuban Missile Crisis, drawing on significant new archival sources only made available in recent years. It challenges prevailing approaches to the Cuban Missile Crisis which attempt to downplay or diminish RFK's role in the successful resolution of this extraordinary thirteen-day period, when the world stood on the brink of nuclear war. It reconciles two contrasting profiles of RFK: the dovish profile set forth by insider accounts and the hawkish one propounded by revisionist historians. This article reveals the role of RFK to have been far more complex, fluid and essential in the successful resolution of the crisis than such rigid demarcations can encompass. This article justifies its assertion across two aspects to RFK's role: firstly, as an advisor in his own right; and, secondly, as de facto Chief of Staff, presidential agent and intermediary for his brother. Quite apart from their individual contributions, taken collectively these amount to an idiosyncratic and unique role. This article argues that it was a role that could not have been fulfilled by any other individual, and without which the crisis may not have been averted.

\section{Introduction}

On a Tuesday morning in October 1962 United States Attorney General Robert F. Kennedy received an urgent phone call from his brother, President Kennedy, informing him that the Thank you to the editor and anonymous reviewers whose generous and honest criticism made this a better article. Thank you to Mum and Dad, who first set me on this path with our passionate dinnertable debates and to whom I owe so much. Thank you to my wife Abigail for her loving support and patience throughout, and all in our beautiful daughter Cora's first year. 
Soviet Union was constructing nuclear missile sites in $\mathrm{Cuba}^{1}$. The weeks that followed remain the closest the world has ever come to nuclear war. The installation of these sites was unprecedented. Nuclear missiles now lay in place merely 90 miles off the US coast, contrary to the express assurances of Soviet Premier Khrushchev to the contrary, and in the face of repeated warnings from President Kennedy in preceding months. Politically and strategically, President Kennedy and his administration had no option but to respond - triggering a stand-off between two nuclear superpowers, each with their own just cause. The stakes involved, and the richness of the primary source material available, make the study of the resolution of this crisis one of the most fascinating and instructive periods in modern history.

This article argues that Robert Kennedy (RFK) was President Kennedy's indispensable partner in the successful resolution of the Cuban Missile Crisis. RFK's role was twofold. First, he was an indispensable advisor in his own right. His unique and particular judgement and counsel to the President throughout the crisis was essential to its successful resolution, and indispensable to the President. Second, RFK acted as de-facto Chief of Staff, Presidential Agent and Intermediary for his brother. ${ }^{2}$ As President Kennedy’s trusted proxy, RFK enabled the President to circumnavigate the often opaque and invariably sluggish formal channels of government but also to gather, organise and relay frank assessments and advice from others, unhindered by presidential deference.

\footnotetext{
${ }^{1}$ Laurence Chang \& Peter Kornbluh, eds., The Cuban Missile Crisis, 1962, (New York, 1998), p. 359.

2 These demarcations of RFK's contribution are not new. See for example Peter Kornbluh, Senior Analyst at the National Security Archive: 'Robert Kennedy was the Chief Advisor, the Chief Confidant and the Chief Secret Intermediary for John F. Kennedy during the Cuban Missile Crisis'. Interview with Marco Werman, 'Robert F. Kennedy's Cuban Missile Crisis Era Papers Released', PRI's The World, 11 October $2012 .<$ https://www.pri.org/stories/2012-10-11/robert-f-kennedys-cuban-missile-crisis-era-papers-released> [accessed 4
} March 2018]. 
It should be noted that both revisionist and post-revisionist perspectives on the Cuban Missile Crisis have contributed much to our understanding of this extraordinary period. They have justly criticised the Kennedy administration's antagonistic policies toward Cuba - the products of a confrontational mind-set fuelled by binary, Cold War ideologies - observing that events such as the Bay of Pigs served only to drive Soviet premier Nikita Khrushchev and Cuban premier Fidel Castro to desperate measures ${ }^{3}$. They have decried, albeit with the benefit of hindsight, the mistaken assumptions made of each other by both US and Soviet administrations - including Khrushchev's breath-taking underestimation of likely US reaction to the placement of nuclear weapons in Cuba. ${ }^{4}$ They have criticised the secrecy of the Jupiter trade and the resulting impact this had on US foreign policy for decades after. All these insights, and more, are important contributions to our understanding of the crisis. But they have failed to fully or fairly assess the scope of RFK's contribution to the handling of the crisis.

RFK's own account of the Cuban Missile Crisis neatly delimits the crisis to thirteen dramatic days: beginning on 16 October 1962, with the first White House briefings on the introduction of nuclear weapons in Cuba, and ending on 28 October with a public announcement from the Soviet Union of their agreement to remove these missiles in exchange for a non-invasion

\footnotetext{
${ }^{3}$ Much has been written of Khrushchev's famous reminiscence: 'The main thing was that the installation of our missiles in Cuba would, I thought, restrain the United Nations from precipitous military action against Castro's government.’ In Strobe Talbott, ed. Khrushchev Remembers (London, 1971), p. 494

${ }^{4}$ Khruschev reportedly said, of the need to place the missiles in Cuba in secret: 'Confront them with an established fact. The Americans are a pragmatic people. They'll accept it, like we had to in Turkey.' In Phillip Knightley and Peter Pringle, 'The Cuban Missile Crisis 1962: The world at death's door', The Independent, 4 October 1992, <http://www.independent.co.uk/voices/the-cuban-missile-crisis-1962-the-world-at-deaths-door-1555622.html $>$ [accessed 3 Feb. 2018]
} 
pledge from the US. ${ }^{5}$ Few crises can be so neatly constrained to such a precise timetable certainly the crisis had its roots far before than October $16^{\text {th }}$ and was not conclusively resolved until several months later. We know for example that overflights to ensure the missiles were removed and not replaced continued well after October $28^{\text {th }}$, and that negotiations to resolve the crisis also continued. ${ }^{6}$ Furthermore, RFK's critical role in the crisis rested upon relationships built long before these thirteen days. Nonetheless, if thirteen days cannot be argued to be the sole window onto the crisis, they were nonetheless its defining moment and the thirteen-day period does provide a distinct focus for justifying RFK's role as President Kennedy's 'indispensable partner'.

Detailed understanding of the Cuban Missile Crisis is possible primarily because of the extraordinary tape recordings of the EXCOMM meetings. EXCOMM, the Executive Committee of the National Security Council, was officially established by National Security Action Memorandum 196 on October $22^{\text {nd }}$, though its members had effectively already been selected and brought together on the first day of the crisis, six days earlier. ${ }^{7}$ This committee,

\footnotetext{
${ }^{5}$ Robert F. Kennedy, Thirteen Days (London, 1969), p. 27.

${ }^{6}$ RFK's crucial involvement in these negotiations is illustrated in Soviet Ambassador Anatoly Dobrynin's account of their continued meetings in his memoir In Confidence (New York, 1995), pp. 94-99.

${ }^{7}$ See National Security Action Memorandum Number 196: Establishment of an Executive Committee of the National Security Council, John F. Kennedy Presidential Library and Museum, 22 October 1962, <http://www.jfklibrary.org/Asset-Viewer/FpD8GSoRtkulLH7uDeAE2w.aspx> [accessed 3 Feb. 2018]. The EXCOMM enlarged the regular membership of the National Security Council, which included, among others, National Security Advisor McGeorge Bundy, Secretary of Defense Robert McNamara, Director of Intelligence John McCone and Secretary of State, Dean Rusk. The additional members brought into the EXCOMM included RFK, White House counsel Theodore Sorensen and former ambassador to the Soviet Union, Llewellyn Thompson.
} 
including RFK and eleven other key advisors across senior government, met regularly over the thirteen-day period. The tapes of this period, enabled by President Kennedy's placement of recording devices in key rooms in the White House, reveal much about the management of the crisis and RFK's role within it.

Despite potential reservations about the EXCOMM tapes, no evidence yet points to RFK being aware of them in $1962 .{ }^{8}$ Furthermore, were he to have been aware of them there is little sign of him self-censoring. To borrow an assessment on JFK, there is 'no evidence that he taped only self-flattering moments. ${ }^{9}$ This appears true of RFK too, as his unreserved proposal of subterfuge and internationally illegal and unethical actions would indicate. ${ }^{10}$

One can track the historiography of RFK's role in the crisis in a parallel arc to that of President Kennedy's own historiography: deferential to a fault in its early days, overstated in its revisionism in recent years. Its chief propagators were invariably the same individuals, close to the administration and often having served at its centre: most notably, Theodore Sorensen, President Kennedy's chief speechwriter and special counsel, and Arthur Schlesinger Junior, special assistant to President Kennedy and speechwriter ${ }^{11}$. Schlesinger termed RFK the

\footnotetext{
${ }^{8}$ RFK 'certainly knew of the tapes and dictabelts by some point in 1963 , (but) it is not clear that (he) had this knowledge earlier.' In Ernest R. May and Philip D Zelikow (ed.), The Presidential Recordings: John F. Kennedy. The Great Crises, vol. 1, (New York, 2001), pp. xvii-xxix

${ }^{9}$ May and Zelikow (ed.), The Kennedy Tapes, p. xii.

${ }^{10}$ RFK raised a controversial CIA proposal during the meetings, effectively a scenario that would enable a pretext for invading Cuba. See May and Zelikow (ed.), The Kennedy Tapes, p. 68.

11 For Arthur Schlesinger and Ted Sorensens's first-hand accounts of the JFK administration, both originally published in 1965, see, respectively, A Thousand Days: John F. Kennedy in the White House (Boston, 2002 edn) and Kennedy (New York, Kindle edn, 2010). For Schlesinger's biography of his friend and sometime boss RFK, originally published in 1978, see Arthur M. Schlesinger Jr., Robert Kennedy and his Times, (New York, Kindle edn, 2012).
} 
'indispensable partner' ${ }^{12}$ and Sorensen edited RFK's memoir for its posthumous publication, crafting a heroic narrative around which advocates of both historiographies could rally.

Subsequently, historians have dismantled the myths around President Kennedy and his administration, including one of its principal moments of glory. ${ }^{13}$ Far from the Cuban Missile Crisis being a heroic and ingenious defence against Soviet aggression, historians such as Sheldon Stern have argued that President Kennedy 'bore a substantial share of the responsibility for (its) onset... ${ }^{14}$ Stern also turns his attention to RFK's role, dismissing the accounts of early historians such as Schlesinger as 'profoundly misleading if not out-and-out deceptive. ${ }^{15}$ Stern, Mark White and other post-revisionists make a number of charges against RFK's involvement in the missile crisis. Some are not directly relevant to the central argument of this article, but it is worth addressing them at the outset as they are useful context.

The first charge, effectively summarised by Mark White, is that the 'heroic interpretation of Robert Kennedy's contribution' is 'rooted' in RFK's own apparently self-serving memoir,

\footnotetext{
${ }^{12}$ Schlesinger Jr., Robert Kennedy and His Times, p. 531.

${ }^{13}$ For one of the most famous attacks on the Kennedy myth see Thomas C. Reeves, A Question of Character: A Life of John F. Kennedy, (New York, 1991). A useful overview can also be found in Dylan Matthews, 'Americans think John F. Kennedy was one of our greatest presidents. He wasn't.' The Washington Post, 22 November 2013, $<$ http://www.washingtonpost.com/news/wonkblog/wp/2013/11/22/americans-think-john-f-kennedy-was-one-ofour-greatest-presidents-he-wasnt>, [accessed 3 Feb. 2018].

${ }^{14}$ Sheldon M. Stern, Averting 'The Final Failure': John F. Kennedy and the Secret Cuban Missile Crisis Meetings, (California, 2003), p. xv.

${ }^{15}$ Stern, The Cuban Missile Crisis in American Memory, p. 34.
} 
Thirteen Days. ${ }^{16}$ White's contention is that, as an insider's account of this most famous of Cold War dramas, early historians took their lead from its chief claims. As he asserts: 'Early historians of the missile crisis tended to echo this account of the attorney general's performance coming, as it were, from the horse's mouth. ${ }^{17}$ This charge is a strong example of the ways in which the post-revisionist perspective on the crisis can be overstated and sometimes selective in its marshalling of supporting facts. Writing before the crisis had even begun, and barely a year after President Kennedy had assumed office, reveals a contemporary view of RFK not incompatible with the leading role revealed in the Thirteen Days memoir. In early 1962, the U.S. News \& World Report published a piece proclaiming RFK's role as 'Assistant President': asserting that 'his influence and importance in the Government go far beyond that of official capacity' and describing him as 'a man who plays an important role in shaping major decisions. ${ }^{18}$ In a December 1962 piece for the Saturday Evening Post, two reporters recounted the events of the crisis in detail, arguing that 'one of the President's main motives in forming ExComm... was to bring his brother into the centre of the policy-forming process', as well as asserting that 'it was Bobby Kennedy who suggested what has since been dubbed 'The

\footnotetext{
${ }^{16}$ In Mark J. White, 'Robert Kennedy and the Cuban Missile Crisis: A Reinterpretation', American Diplomacy. 9 September 2007, [http://www.unc.edu/depts/diplomat/item/2007/0709/whit/white_rfk.html> [accessed 4 Feb. 2018] A number of scholars have further argued that RFK's ambition for the Presidency shaped his account of the Cuban Missile Crisis, even before his brother's death. See Stern, The Cuban Missile Crisis in American Memory, p. 35 .

${ }^{17}$ Ibid.

18 'Bobby Kennedy: Is He the 'Assistant President'?', U.S. News \& World Report, 19 February 1962, < https://www.usnews.com/news/articles/2015/06/05/bobby-kennedy-is-he-the-assistant-president>, [accessed 4
} Feb. 2018] 
'Trollope Ploy.' ${ }^{19}$ (A stratagem for navigating two very different proposals from Khrushchev on the evening of October 26th and the morning of October 27th: the former conciliatory and essentially requiring a simple promise that the US not invade Cuba; the latter announced publicly and calling for the removal of American Jupiter missiles from Turkey.) In forewords to Kennedy's memoir, British Prime Minister Macmillan spoke of Robert Kennedy's role in the crisis as a 'leading part', second only to the President himself, heralding him as 'adjutant' ${ }^{20}$; while Secretary of Defence McNamara declared the smooth cooperation of several agencies of government during the crisis as being 'in large part a result of the efforts of Robert Kennedy', and corroborated RFK's role in 'The Trollope Ploy.' 21

Two key cornerstones of the revisionist view are therefore infinitely more complex than their confident assertions indicate. Firstly, the notion that RFK's predominant role, and its successes, were a retrospective narrative - in fact, commentators were already writing of such a role both

\footnotetext{
${ }^{19}$ Stewart Alsop and Charles Bartlett, 'In Time of Crisis, The Saturday Evening Post, 8 December 1962, < http://www.saturdayeveningpost.com/wp-content/uploads/satevepost/1962-12-08-missile-crisis.pdf> [accessed 4 Feb. 2018]. 'The Trollope Ploy' refers to the decision to reply to the first of two apparently contradictory letters sent by Khrushchev in the space of 24 hours as the crisis came to a close. It is a reference to a plot device by novelist Anthony Trollope, 'in which a woman interprets a pro-forma romantic gesture as a proposal of marriage.' In Ernest R. May and Philip D Zelikow (ed.), The Presidential Recordings: John F. Kennedy. The Great Crises, vol. 2, (New York, 2001), p. 213

${ }^{20}$ Robert Kennedy, Thirteen Days, p. 15. Macmillan was consistent in this position, continuing to emphasise the preeminent and positive influence of RFK on the President in his own memoir of the crisis, see Harold Macmillan, At the End of the Day, (London, 1973), p. 184 and p. 214. However, we must note Macmillan's perceptive line, in a comment on Secretary Rusk's famous aside declaring that the Russians 'flinched': 'Perhaps it was not quite so simple as that'. (Robert Kennedy, Thirteen Days, p. 16)

${ }^{21}$ Robert Kennedy, Thirteen Days, p. 20.
} 
prior and immediately after the crisis. Secondly, the view that RFK was himself the chief propagator of his predominant and crucial role - in fact, others had spoken to that effect far earlier, and several key participants corroborated his perspective. With this context in mind, neither RFK's memoir, nor the crisis dynamics it describes, can or should be completely disregarded. Stern, for example, continues to quote a second-hand exchange between RFK and Kenneth O'Donnell, JFK's special assistant and confidante during the crisis, to undermine the veracity of RFK's memoir Thirteen Days. On reading the account, Kenneth O'Donnell is said to have exclaimed, 'I thought your brother was President during the missile crisis!' whilst RFK replied, 'He's not running (for office), and I am. ${ }^{22}$ Yet a second-hand account of a comment by someone who didn't participate in most of the EXCOMM meetings should surely not be given so much prominence. ${ }^{23}$ Thus the post-revisionist view should be treated with as much caution as the revisionist and heroic narratives.

To address the post-revisionist view this article argues for a reappraisal of RFK's central role in the resolution of the crisis, one which acknowledges the unique and indispensable support he provided the President as brother, administration member and confidant. Quite apart from the individual contributions involved in these three elements, taken collectively these amount to an idiosyncratic and unique role - more a Presidential partner than advisor. When viewed through this prism of Presidential partnership, RFK's role reveals itself to have been far more

\footnotetext{
${ }^{22}$ Sheldon M. Stern, 'Beyond the smoke and mirrors: the real JFK White House Cuban missile crisis', in Len Scott and R. Gerald Hughes (ed.) The Cuban Missile Crisis: A Critical Reappraisal, (New York, 2015), p. 207. For the source of this quotation see Ibid, p. 222.

${ }^{23}$ Mark White. 'The Cinematic Kennedy: Thirteen Days and the Burnishing of an Image', in I.W. Morgan (eds) Presidents in the Movies. The Evolving American Presidency Series. (New York, 2011)
} 
complex, fluid and essential in the successful resolution of the crisis than the rigid demarcations of either early historiography or post-revisionist perspectives.

\section{RFK as an indispensable advisor in his own right}

In assessing RFK's performance as an advisor in his own right during the crisis, we are really talking about his unique and particular judgement and counsel as events transpired; not the skill with which he aggregated and articulated the views of EXCOMM, nor the success with which he was an intermediary or agent for his brother, but rather his own analysis and instinct for managing the crisis to resolution. As long as there have been articles written about JFK, writers have observed the intimate role of his brother Robert - not merely as a close family member, but as a close advisor and even partner. Contemporary newsmen and commentators first heralded the younger brother's role in JFK's political campaigns ${ }^{24}$ - a role which grew in stature with each successive campaign, manifestly in recognition of RFK's successful qualities. For their working relationship was by no means a familial certainty ${ }^{25}$ but one earned in the crucible of political endeavour. Of course, the exact breadth and nature of these qualities was debated then and remains a source of debate now. What can be concluded with some confidence is RFK's tenaciousness and his dogged pursuit of his brother's ambition. By 1960, it had

\footnotetext{
${ }^{24}$ For an early article on the collaboration of the two brothers, see 'The Rise of the Brothers Kennedy' in Look, 6 August 1957.

${ }^{25}$ Kenneth O'Donnell, close friend to both brothers and later the President's special assistant, wrote of his surprise, in bringing RFK into JFK's 1952 senate campaign, that the brothers were not 'peas in the pod'; actually that 'neither one cared very much what either one was doing'. Quoted in Thomas, Robert Kennedy: His Life, p. 59.
} 
become clear that RFK was the 'only choice' as campaign manager for JFK's presidential bid. ${ }^{26}$ And although contemporary commentators were surprised at his appointment as Attorney General, they cannot have been surprised that the new President ensured his younger brother had a central role in his subsequent administration. The appointment had cemented a progression from family member, to supportive campaign manager, to political collaborator and finally to a central advisor of his Presidency.

Precisely because of his familial intimacy with the President, RFK could speak truth to power. There was a consensus amongst presidential advisors that RFK's voice was a uniquely personal one, able to cut through to the President where others could not. White House Press Secretary Christine Camp described RFK's position as being in the innermost circle of Presidential advisors, privileged above all others as JFK's 'close friend and confidante' ${ }^{27}$. In 1961, RFK could raise the spectre of nuclear emplacement on Cuba mere days after the President had suffered the greatest blow of his Presidency at the Bay of Pigs, a time when JFK least wanted to hear it. National Security Advisor, McGeorge Bundy, would later candidly acknowledge the potential for RFK to completely overturn a presidential agreement secured through Bundy's own counsel, remarking on a policy memo: 'I have cleared this in principle with the President (altho I would not exclude a shift if Bobby felt strongly the other way). ${ }^{28}$

\footnotetext{
${ }^{26}$ Schlesinger Jr., Robert Kennedy and His Times, p. 192.

${ }^{27}$ Christine Camp Oral History Interview, John F. Kennedy Library (JFKL), Oral History Collection (OHC), 1969, p. 124.

${ }^{28}$ Foreign Relations of the United States, 1961-1963, Volume XI, Cuban Missile Crisis and Aftermath, eds. Edward C. Keefer, Charles S. Sampson and Louis J. Smith (Washington: Government Printing Office, 1996), Document 345.
} 
Of course, other advisors to JFK abounded, whether fellow members of the cabinet or similar personal advisors such as Sorensen. Prior to April 1961, RFK was an important but not an indispensable part of his brother's Administration. The Bay of Pigs fiasco that month represented a turning point in the brothers' relationship, one which it is crucial to understand when considering the Cuban Missile Crisis.

Briefly put, JFK learnt from the Bay of Pigs fiasco of the limits to, and dangers of, organisational reliance. The President's actions in the aftermath of the crisis spoke loudly to a conspicuous advancement of RFK's role in his administration, beginning with his appointment to help lead a committee examining the causes of the disaster. ${ }^{29}$ "(He) was the man assigned to scrutinize and regroup his brother's counselors so that a Bay of Pigs could never happen again.”30 This was indicative not only of an appreciation of RFK's judgment and counsel but also his unique potential to cut through and circumnavigate the bureaucratic failings which had dogged the Bay of Pigs. ${ }^{31}$ RFK fulfilled his role zealously, taking lessons for the administration, his brother, and himself, lessons he would bring to the Cuban Missile Crisis. First was his instinctive distrust of the military chiefs, with their misplaced confidence in the

\footnotetext{
${ }^{29}$ See William Z. Slany, 'Preface', Foreign Relations Of The United States, 1961-1963, Volume X, Cuba, January 1961-September 1962, (FRUS,1997). This was also formally confirmed by President Kennedy in an official letter dated April 22, 1961 cited in Jack B. Pfeiffer, The Taylor Committee Investigation of the Bay of Pigs, Central Intelligence Agency, (Washington, 1984), p. 11. Available here: https://nsarchive2.gwu.edu/NSAEBB/NSAEBB355/bop-vol4.pdf [accessed 19 Aug. 2018]

${ }^{30}$ Michael R. Beschloss, The Crisis Years: Kennedy and Khrushchev 1960-1963 (New York, 1991), p. 304.

${ }^{31}$ See James W. Hilty, Robert Kennedy: Brother Protector, (Philadelphia, 1997), p. 417.
} 
comprehensiveness of their intelligence, their playbook-approach to Soviet 'aggression' and their failure to anticipate likely Soviet responses. ${ }^{32}$ Second, his dogged questioning of proposed courses of action to ensure JFK heard everything he thought he needed to, loudly and clearly enough. ${ }^{33}$ Third was his innate understanding of the crisis as more a political struggle than a military one, with its own limitations. ${ }^{34}$

The lessons RFK derived from the Bay of Pigs review had a direct impact on the successful resolution of the subsequent Cuban Missile Crisis. On first receipt of the famous U-2 photographs revealing the placement of Soviet missiles in Cuba, the JFK administration was united in shock. This was because the bureaucracy around them had concluded that, strategically, the Soviets would not do so. As the President himself would remark on the first day of the crisis, "not many of us thought that he (Khrushchev) was going to put MRBMs on Cuba $^{35}$. Only two of JFK's advisors had seriously considered otherwise and articulated their thoughts to the President - CIA Director John McCone ${ }^{36}$ and Attorney General Robert

\footnotetext{
${ }^{32}$ Consider the notes from RFK's private files: "Intelligence estimate on Air Force was off," and '...indicates what really bad work J.C.S [Joint Chiefs of Staff] did on the whole matter. The plan as they approved it would have been even more catastrophic than the one that finally went into effect." Papers of Robert F. Kennedy. Attorney General Papers. Attorney General's Confidential File. 6-2-2: Cuba: RFK personal notes. RFKAG-215-003. John F. Kennedy Presidential Library and Museum.

33 'I don't think Jack knew the significance of calling off strikes.' Ibid.

34 'Political limitation on military activity. This should be known and understood by those who are planning a project. If impossible to proceed with these limitations project should be cancelled.' Ibid.

${ }^{35}$ May and Zelikow (ed.), The Kennedy Tapes, p. 60

${ }^{36}$ May and Zelikow (ed.), The Kennedy Tapes, pp. 60-61
} 
Kennedy, the latter writing to his brother as early as April 1961: 'If we don't want Russia to set up missile bases in Cuba, we had better decide now what we are willing to do to stop it. ${ }^{37}$

RFK's early warning revealed several qualities highly relevant to his role as advisor during the missile crisis. He was unremittingly open-minded. RFK was not one to close the book on an issue merely because the 'experts' had. He had learnt the hard way that departmental experts should not be followed blindly. Specifically, as his private notes on the Bay of Pigs indicate, he judged 'underestimation' by the US of Castro's forces as a key cause of the fiasco ${ }^{38}$. RFK went so far as to conclude that, had the administration known the extent of Castro's forces, the invasion would never have had approval: '(the administration) never would have tried this

\footnotetext{
${ }^{37}$ May and Zelikow (ed.), The Kennedy Tapes, p. 1. RFK would also remind his brother of this warning during the crisis. Ibid, p. 220 and p. 468. RFK's prescience on this issue continues to be overlooked in recent histories of the crisis, which consistently emphasise the intelligence community's failure in predicting the deployment of Soviet nuclear forces in Cuba, whilst ignoring the voice of RFK, a highly involved member of the intelligence community. See, for example, Len Scott, 'The 'Incredible Wrongness' of Nikita Khrushchev: The CIA and the Cuban Missile Crisis', History, 100 (340), p. 228 and Robert Jervis, 'The Cuban missile crisis: What can we know, why did it start, and how did it end?' in Len Scott and R. Gerald Hughes, eds., The Cuban Missile Crisis: A Critical Reappraisal (London, 2015), p. 1. Correcting this oversight is important, as left unchallenged it is in danger of perpetuating itself. It also means that inferences are made by historians on the crisis which ought to be more qualified - namely that US reaction could have been different had there been greater foresight and preparedness.
}

\footnotetext{
${ }^{38}$ One handwritten note criticises the 'underestimation of Cuban air force generally, as well as the vigor and determination of Castro ground forces'. In Robert F. Kennedy, Declassified Cuban Missile Crisis Papers (National Archives, 1962). <http://www.paperlessarchives.com/cuban-missile-crisis-rfk-files.html>, [accessed
} 16 Feb. 2018] 
operation if knew that Cuba forces were as good as they were. ${ }^{39}$ Fast forward from April 1961 to a September 1962 meeting (by which time, unbeknownst to the US, Russian missiles were on their way to Cuba), and JFK's own National Security Advisor, McGeorge Bundy, reasserted the improbability of surface-to-surface missile emplacements in an exchange with RFK, calling them 'a much larger step than...the kind of thing we've seen', effectively echoing the latest National Intelligence Estimate ${ }^{40}$. Yet RFK pressed the President's advisors to look beyond the immediate build-up they were aware of and consider 'Cuba in the future': '...this is going to continue... eventually it's very likely...that they'll put surface-to-surface missiles in. ${ }^{41}$ RFK then proceeded to consider and outline the steps the government could take, presciently including invasion and blockade. RFK's concern not to underestimate his opponents also led him, five months before the crisis, to instruct officials from the Departments of State and Defense, as well as the CIA, to investigate possible responses to the establishment of a military base in Cuba. ${ }^{42}$ As a direct result of RFK's personal direction, the key government departments tasked with handling the Cuban Missile Crisis were extraordinarily well-prepared in contingencies and intelligence. ${ }^{43}$

\footnotetext{
39 Ibid.

${ }^{40}$ May and Zelikow (ed.), The Kennedy Tapes, p. 7. See also White, The Kennedys and Cuba, p. 157.

${ }^{41}$ May and Zelikow (ed.), The Kennedy Tapes, p. 6.

${ }^{42}$ Memorandum for the Special Group (Augmented), May 31, 1962 in Foreign Relations of the United States, 1961-1963, Volume X, Cuba, January 1961-September 1962, ed. Louis J. Smith (Washington: Government Printing Office, 1997), Document 341.

${ }^{43}$ See also RFK's insistence that U-2 Cuba overflights continue despite concerns following the shooting down of a U-2 over China. In Max Holland and David M. Barrett, Blind Over Cuba, (Texas, 2012), pp. 87-94.
} 
RFK did not shy from considering a difficult problem and the difficult courses of action its resolution might entail - the 'what we are willing to do to stop it' he first put forward to his brother in 1961. This 1961 letter to the President and his undaunted exchange with Bundy a month before the crisis, also illustrates RFK's proactive character and confidence. RFK continuously sought to probe issues - to get the facts, to look at all options for handling an issue. Such advice invariably had an impact on the President. To return to the September 1962 exchange, JFK left his brother the space to explore his chain of thought in a lengthy soliloquy on the prospect of Soviet missile emplacements in Cuba, before turning to RFK on a press statement already drafted and directly asking his advice (which was to confront the question of missiles in the statement), eventually directing the assembled group to implement it - 'the key thing you need right now are these missiles. ${ }^{44}$ This small exchange is considerably significant. The President is so confident in RFK's advice that he is prepared to effectively hand over the meeting to his younger brother. Reflecting on this counsel, he then proactively seeks additional advice from him.

Two important conclusions can be noted here. First, that RFK was already providing the President with unique advice on Cuba-related issues well before the crisis. Second, that this advice had a clear impact on the President. This meant that RFK had at his disposal months of thought and analysis on Cuba-related issues, both his own and others ${ }^{45}$, that he could refer to the President's benefit throughout the crisis. Crucially, he had also proven himself successful

\footnotetext{
${ }^{44}$ May and Zelikow (ed.), The Kennedy Tapes, pp. 7-8.

${ }^{45}$ Consider, for example, his listing of three alternative means to 'prevent that island (Cuba) from becoming $\mathrm{Mr}$. Khrushchev's arsenal', including invasion and two varieties of blockade. White, The Kennedys and Cuba, pp. 35-
} 36. 
in getting such advice heard, he knew what would resonate with the President and had an instinctive grasp of the President's likely position on these issues.

Scholarship on RFK's role in the Cuban Missile Crisis - whether original, revisionist or otherwise - invariably looks at two specific claims when assessing his role in originating advice. These are that RFK was an early, and the foremost, proponent of the blockade and that he was chiefly responsible for the 'Trollope Ploy.' These assertions require reassessment.

\section{i. The Blockade Decision}

Scholars have disagreed about RFK's role in the decision to blockade Cuba. In their 1962 Saturday Evening Post article, recounting the air strike/blockade debate, Alsop and Bartlett summarise: 'Robert Kennedy, surprisingly, was the leading dove. ${ }^{46}$ Revisionist Benjamin Schwarz has alternatively argued that RFK '...was among the most consistently and recklessly hawkish of the president's advisors, pushing not for a blockade or even air strikes against Cuba but for a full-scale invasion as "the last chance we will have to destroy Castro".,47

Both histories have their faults. RFK neither claimed to have originated the blockade route, nor did he actually do so. As he himself recorded in his memoir: 'I supported McNamara's position

\footnotetext{
${ }^{46}$ Alsop and Bartlett, 'In Time of Crisis'.

47 Benjamin Schwarz, 'The Real Cuban Missile Crisis', The Atlantic, January/February 2013 Issue, http://www.theatlantic.com/magazine/archive/2013/01/the-real-cuban-missile-crisis/309190/?single_page=true [accessed 16 Feb. 2018].
} 
in favor of a blockade. This was not from a deep conviction that it would be a successful course of action, but a feeling that it had more flexibility and fewer liabilities than a military attack. ${ }^{48}$ This is one example of several in the primary source material which shows a nuance in RFK's advice often set aside in binary views on RFK and the crisis. RFK's frank admission ('not from a deep conviction') does not diminish the importance of his role - quite the opposite in fact. It reveals an individual who did not solely view his role as an advisory one, only throwing up alternative options for President Kennedy's decision or vehemently advocating his own approach without recourse to debates with other advisors or the movement of events. It reads instead as the words of a highly reflective individual, influenced by others but still wary of the chosen option. This touches upon both the Chief of Staff and intermediary roles discussed later. It also shows how the primary source material often marshalled by RFK's critics can be reconciled with the more flattering contemporaneous accounts.

Critics such as Stern, far from viewing RFK as a leader of the doves (through his support for the blockade route), point to the primary source material and advocate his role as a dangerous hawk advocating invasion from the outset. In evidence for this assertion, Stern directly quotes RFK: 'We should just get into it, and get it over with and take our losses if he wants to get into a war over this... ${ }^{49}$ From these 'first remarks' which make 'his own extremely provocative positions clear from the very first meeting, ${ }^{50}$ Stern argues that RFK's memoir of the crisis was

\footnotetext{
${ }^{48}$ Robert F. Kennedy, Thirteen Days, p. 29 (emphasis added).

${ }^{49}$ Stern, 'Beyond the smoke and mirrors: the real JFK White House Cuban missile crisis', , p. 214.

${ }^{50}$ Ibid.
} 
'an effort to manipulate the history of the missile crisis' ${ }^{51}$ and 'invent the past' ${ }^{52}$. A 'consistently hawkish' figure emerges from Stern's analysis of RFK, one 'in sharp contrast to his brother. ${ }^{53}$

Yet this analysis is skewed, for Stern quotes RFK out of context, paring back RFK's words selectively to support his argument. The above quotation actually begins with a series of qualifications, as RFK tentatively hedges his comments:

Now (think) whether it wouldn't be the argument, if you're going to get into it at all, whether we should just get into it, and get it over with, and take our losses. And if he wants to get into a war over this...Hell, if it's war that's gonna come on this thing, he sticks those kinds of missiles in after the warning, then he's gonna get into a war over six months from now, or a year from now on something. ${ }^{54}$

In analysing RFK's contribution here we must remember that this quote comes from the first day of the crisis, the evening of Tuesday $16^{\text {th }}$ October, at a time when the EXCOMM group was endeavouring to lay out all options and when no sensible participant could yet profess to a final, resolved view. Consider for example that most eminently sensible of participants, McNamara, who qualified when first outlining the blockade route in that same meeting, 'I don't

\footnotetext{
${ }^{51}$ Ibid, p. 212.

${ }^{52}$ Ibid, p. 209.

${ }^{53}$ Ibid, p. 208.

${ }^{54}$ May and Zelikow (ed.), The Kennedy Tapes, p. 66. See also Foreign Relations of the United States (FRUS), ‘Cuban Missile Crisis and Aftermath', Foreign Relations of the United States, 1961-1963, Volume XI, Office of the Historian, Bureau of Public Affairs, United States Department of State. 21. Off the Record Meeting on Cuba, Washington, October 16, 1962, 6:30-7:55 p.m.
} 
want to argue for this because I don't...think it's a perfect solution by any means. ${ }^{55}$ There were still several days of in-depth planning that needed to take place before any sensible advisor could be confident in their proposed course of action. Taking RFK's quote in the round, therefore, it can be seen not as a belligerent exhortation, but a qualified question - effectively placing invasion on the table as another alternative. As will be seen later, RFK took a very different approach when directly advocating a position and certainly did so without such qualification. ${ }^{56}$

His speculative question here also followed an earlier interjection into the President's summary of 'potential operations', pointing out that 'we have the fifth one, really, which is the invasion. ${ }^{57}$ This was RFK demonstrating indispensable qualities as an advisor to the President. In prodding and probing the EXCOMM members, in 'seeking alternatives for his brother, RFK helped to broaden the President's range of alternatives, which was precisely what was required on the first day of the crisis, as all participants continued to reserve final judgment, cognisant of the need for any mooted options to be thoroughly conceived and evaluated, inside and outside EXCOMM, before any decisions were to be made. It was a role best articulated by McGeorge Bundy, National Security Advisor during the crisis: Robert Kennedy's function was

\footnotetext{
${ }^{55}$ Ibid, p. 71.

${ }^{56}$ See also the audio itself and RFK's searching delivery: http://microsites.jfklibrary.org/cmc/oct16/doc3.html (beginning 00:49:05).

${ }^{57}$ May and Zelikow (ed.), The Kennedy Tapes, p. 47.

${ }^{58}$ Hilty, Robert Kennedy, p. 445.
} 
'to go and prod and poke people into doing their best, and staying with the problem, and not giving up until we got a better answer. He was that kind of a terrier of a man. ${ }^{59}$

Seen in such a context, RFK's pressing for a reduction in the invasion lead-time ${ }^{60}$ was not a 'contentious demand' from a belligerent man champing at the bit, to paraphrase $\operatorname{Stern}^{61}$, but rather the pushing and probing so crucial to the President by ensuring each alternative open to him was the best iteration it could be, and that no group had been allowed to expound their proposal without challenge.

Here we also see the merits of an advisor such as RFK operating across departmental disciplines, as JFK would later observe: 'The people who were involved had particular responsibilities of their own ...'62 Ernest May and Philip Zelikow refer to these constraints as 'action responsibility', constraining departmental leaders to 'agendas of their own.' ${ }^{63}$ Richard Neustadt takes this further, noting that advisors are 'bound to judge (the President's) preferences in the light of their own responsibilities, not his. ${ }^{64}$ By contrast, RFK's intimacy with his brother, and the confidence that leant him in presidential forums, as well as the extra-

\footnotetext{
${ }^{59}$ Ibid, pp. 407-408.

${ }^{60}$ May and Zelikow (ed.), The Kennedy Tapes, pp. 48-9.

${ }^{61}$ Stern, The Cuban Missile Crisis in American Memory, p. 42.

${ }^{62}$ John F. Kennedy, 'After Two Years: a Conversation With the President', $C B S, A B C$ and NBC, 17 December 1962, <https://www.youtube.com/watch?v=9W9CpLK7I1c> [accessed 16 Feb. 2018].

${ }^{63}$ May and Zelikow (ed.), The Kennedy Tapes, p. 446.

${ }^{64}$ Quoted in Graham T. Allison, Essence of Decision, (Boston, 1971), p. 148.
} 
departmental involvement conferred on him after the Bay of Pigs ${ }^{65}$, enabled him to question departmental leaders with a confidence few others could replicate and in a manner which linked the diverse concerns at play.

In constructing their invasion plans, the Chiefs were focused on military efficacies. Yet RFK was able to see the international political dimension that could ultimately preclude the invasion itself: when the missile emplacements were announced publicly and the Soviets could then make their response to the world 'the United States is going to be under such pressure by everybody not to do anything, ${ }^{66}$. RFK knew that reducing the invasion lead-time could be a key factor in ensuring the invasion was still a practicable option in the face of world opinion. As the meetings progressed, and his support for the blockade route solidified, he also knew that there was a significant likelihood an invasion would be necessary - if the blockade proved ineffectual. In a memorandum to JFK on October $20^{\text {th }}$, Sorensen explained why: 'Inasmuch as a clean, swift strike has been abandoned as militarily impractical...the more widespread air attack will inevitably lead to an invasion. ${ }^{97}$ This example underscores RFK's unique and indispensable contribution as an advisor to the President. Only RFK had the extra-departmental involvement and neutrality that first sparked his advice on the need to reduce the invasion leadtime, whilst also affording him the confidence to proactively question departmental leaders on

\footnotetext{
${ }^{65}$ Larry Tye goes as far as to describe RFK as 'de facto CIA and national security chief...not just the attorney general'. Interview with Sacha Pfeiffer, 'Declassified Papers Provide New Window Into RFK's Role As JFK's Closest Adviser', WBUR News, 11 October 2012. It should also be noted that JFK actually explored such a role with RFK after the Bay of Pigs. See Robert F. Kennedy, in recorded interview by John Bartlow Martin, March 1 1964, John F. Kennedy Oral History Program, John F. Kennedy Library, p. 58.

${ }^{66}$ May and Zelikow (ed.), The Kennedy Tapes, p. 49.

${ }^{67}$ Ted Sorensen, Counselor: A Life at the Edge of History, (New York, Kindle edn, 2008), p. 399.
} 
matters of their own expertise. That RFK continued to question this issue, even whilst his support for other courses of action solidified, underscores that neutrality - that sense that RFK's agenda was not departmental, but rather Presidential. This was indispensable to the President throughout the crisis, ultimately ensuring its successful resolution by providing the President with an advisor that continued to question and probe and to do so with the President's interests always superseding narrow departmental concerns.

A further assertion from revisionist critics such as Stern is that RFK's approach was in 'sharp contrast to his brother' ${ }^{68}$. Again, this assertion must be challenged. On the first day of the crisis, RFK held a Mongoose meeting in the afternoon. A memorandum of the meeting records: 'He made reference to the change in atmosphere... and asked some questions about the percentage of Cubans whom we thought would fight for the regime if the country were invaded. ${ }^{69}$ This quote is often used to depict RFK's more belligerent views, arguing that to contemplate invasion so early in the crisis is to be expected of the pugnacious champion of Operation Mongoose. In this hypothesis the missile crisis represented an opportunity for RFK's long-held ambitions to reclaim Cuba from communism. Yet, tellingly, these questions from RFK proceeded a morning meeting of the EXCOMM in which the final exchange concerned a possible invasion of Cuba, with President Kennedy concluding: 'I wonder if CIA could give us...the latest on his (Castro) popular (support/opposition) ... so we get some idea about our reception there'.70 Indeed, in RFK's notes on the crisis, declassified in 2012, one line from this

\footnotetext{
${ }^{68}$ Stern, 'Beyond the smoke and mirrors: the real JFK White House Cuban missile crisis', p. 214.

${ }^{69}$ White, The Kennedys and Cuba, p. 172.

${ }^{70}$ May and Zelikow (ed.), The Kennedy Tapes, p. 53.
} 
meeting reads, 'Pres asked about morale of Cuban people and attitude'71. RFK's questions in the Mongoose meeting, whilst further underscoring his probing and poking quality, also illustrates that far from these 'provocative' questions about an invasion representing a personal agenda they were informed by a keen understanding of JFK's requirements.

During the Cuban Missile Crisis, there were no good options. In hindsight we know the blockade route 'worked'. However, in the early stages of the crisis President Kennedy was faced with an air strike option which was far from surgical (the military could not guarantee all missiles would be hit and advised extensive sorties to even get close), or a blockade route with highly uncertain outcomes. As President Kennedy himself recalled in an interview later that year, 'whatever action we took had so many disadvantages to it, and each action that we took raised the prospect that it might escalate ${ }^{72}$. The notion of resolving the threat from Cuba altogether, with some form of invasion, was therefore an entirely logical option ${ }^{73}$, particularly when one considers that these Soviet missile emplacements represented the realisation of the administration's worst fears. To the judgment of President Kennedy and his brother it showed that doing 'nothing' for the 18 months after Bay of Pigs had failed to deter the introduction of nuclear weapons. Reeling in all this knowledge in the first 12 hours of hearing the news, the blockade option must have seemed ineffectual and the strikes only a temporary fix which

71 Robert F. Kennedy, Declassified Cuban Missile Crisis Papers (National Archives, 1962). <http://www.paperlessarchives.com/cuban-missile-crisis-rfk-files.html>, [accessed 16 Feb. 2018].

72 John F. Kennedy, 'After Two Years: a Conversation With the President'.

${ }^{73}$ It was certainly seen as logical by others. Prime Minister Harold Macmillan's initial reaction was to argue that the President ought 'to seize Cuba and have done with it', given doubts on the blockade achieving its objectives and its legal basis. See Peter Catterall, 'At the End of the Day: Macmillan's Account of the Cuban Missile Crisis', International Relations, 26(3), p. 272. 
'Soviet aggression' would inevitably overturn. RFK's indispensable role ensured that a range of alternatives were brought to the table and fully considered before the Administration acted in such a volatile situation.

\section{ii. The Blockade Decision}

As the days progressed, a recurring theme in RFK's personal contribution to the deliberations was his insistence on portraying a tough stance to the Soviets while remaining, as George Ball described, 'a force for caution and good sense' within the White House. ${ }^{74}$ As ever, RFK's pursuit of this stance was unique in its energy and resolve but rooted in a keen awareness of the President's own instincts. And few others were able to bridge the hawk/dove divide in this way, and to do so in a way which had a pivotal impact on the President, his advisors, and the resolution of the crisis.

President Kennedy continuously tasked his brother to convey his resolve to the Russian Premier $^{75}$, paranoid about appearing weak after Khrushchev's dominating turn at the Vienna Summit of $1961 .^{76}$ But JFK's stance in public also sprang out of a conviction, as the President

\footnotetext{
${ }^{74}$ Hilty, Robert Kennedy, p. 445.

${ }^{75}$ In a conversation over Berlin, when Bolshakov questioned whether the President had the guts for war over Berlin, RFK replied: 'He does, I know. Tell Khrushchev that.' Quoted in Richard Reeves, President Kennedy: Profile of Power, (New York, 1994), p. 302.

${ }^{76}$ In assessing Vienna JFK said, 'He just beat the hell out of me. I've got a terrible problem if he thinks I'm inexperienced and have no guts'. Quoted in Nathan Thrall and Jesse James Wilkins, 'Kennedy Talked,
} 
later summarised, that 'in matters of national will and world leadership...appearances contribute to reality. ${ }^{77}$ Just as the President knew that the missiles did not practically change the nuclear threat ${ }^{78}$ but nonetheless had an acute impact on the balance of power and political consequences for fault-lines such as Berlin, so too did the President appreciate that Soviet perceptions of American 'resolve' would have a conclusive influence on their own response to the crisis. The Americans' tough stance proved significant. Measures taken to ready the American military, navy and air force for war - including those preparations required to reduce invasion lead-time - were being closely watched by the Soviet Union and heightened 'tension' in Moscow. ${ }^{79}$ Khrushchev's memoirs emphasise this aspect when referencing Dobrynin's meeting with RFK on October $27^{\text {th }}$, tellingly highlighting 'that the military men were putting heavy pressure on (President Kennedy)' and extolling RFK for being 'frank and open' about this. ${ }^{80}$ Bernstein and others have observed that such recollections were published well after the crisis and may not be entirely honest. As Bernstein observed, the military theme 'allowed Khrushchev to present himself as a man of peace - a leader who had rescued Kennedy from his bellicose generals and admirals. ${ }^{, 81}$ Khrushchev's recollection of Dobrynin's cable certainly

Khrushchev Triumphed', The New York Times, $22 \quad$ May 2008, <http://www.nytimes.com/2008/05/22/opinion/22thrall.html?_r=0> [accessed 16 Feb. 2018].

${ }^{77}$ Sorensen, Kennedy, p. 1146.

${ }^{78}$ As JFK wryly observed on the first day of the crisis, 'they've got enough to blow us up now anyway'. Quoted in May and Zelikow (ed.), The Kennedy Tapes, p. 62.

${ }^{79}$ See Dobrynin, In Confidence, p. 91.

${ }^{80}$ Nikita Khrushchev, Memoirs of Nikita Khrushchev: Volume 3, Statesman (1953-1964), (Pennsylvania, Kindle edn, 2007), p. 339.

${ }^{81}$ Barton J. Bernstein, 'The Cuban Missile Crisis: Trading the Jupiters in Turkey?', Political Science Quarterly, 95,1 (1980), p. 123. 
does dramatise the original tone, even talking up the possibility of JFK's military overthrow. ${ }^{82}$ Yet the theme of military pressure is certainly clear in Dobrynin's original cable of $27^{\text {th }}$ October, including such alarming reports as:

'The military is demanding that the President...respond to fire with fire.'

'If we (i.e. the US) start to fire in response - a chain reaction will quickly start that will be very hard to stop.'

'There are many unreasonable heads among the generals, and not only among the generals, who are 'itching for a fight' 83 .

This sense of impending military action, and the pressures behind it, had a profound effect on the Soviet assessment of the situation. Partly, no doubt, because they were not surprising and tallied with earlier accounts. A report six months earlier from a GRU officer in Washington, Colonel Georgi Bolshakov, who held repeated back-channel meetings with RFK, reported RFK telling of the power and independence of the Joint Chiefs of Staff ${ }^{84}$. As Robert Jervis has recently observed, 'evidence from the Soviet side indicates that a purely diplomatic approach would have failed. ${ }^{85}$ As another analyst has noted, 'a less confrontational solution to the

\footnotetext{
${ }^{82}$ Strobe Talbott, ed. Khrushchev Remembers, pp. 497-8

${ }^{83}$ Cold War International History Project Bulletin, 5 (Spring 1995), p. 79-80.

${ }^{84}$ Aleksandr Fursenko and Timothy Naftali, One Hell of a Gamble": Khrushchev, Castro, and Kennedy, 19581964, (New York, 1998).p. 185

${ }^{85}$ Robert Jervis, The Cuban missile crisis', p. 6.
} 
immediate crisis could have resulted in a more dangerous world. ${ }^{86}$ They were clearly intended by RFK too, as his personal files show. In referring to the meeting in his hand-written notes, he writes: 'Purpose of talking to Dob - was to emphasize danger. ${ }^{87}$ RFK was clearly successful in emphasising that danger to Dobrynin and, through Dobrynin, Khrushchev. It is also clear that this message carried unique credibility appearing, as it did, consistent with previous RFK/Soviet interactions and underscored by the highly personal tone of RFK's delivery. As noted earlier, we also know that this had an impact on Khrushchev, informing the actions he subsequently took to help resolve the crisis. This is another illustration of the uniqueness of RFK's contribution, given the weight carried to his messages as Presidential brother and intimate, but also his successful delivery of them.

At the same time, in private RFK continued to advocate a balanced approach, passionately advocating the blockade route. In a decisive meeting on October $20^{\text {th }}$, RFK advocated a 'combination of the blockade route and the air strike route', arguing for an initial blockade to be followed by an air strike in the event the Russians 'did not halt the development of the missile capability ${ }^{98}$. This pairing was a turning point for building EXCOMM consensus, ass JFK would later note: 'The course we finally adopted had the advantage of permitting other steps if this one was unsuccessful...I would think that the majority finally came to accept that,

\footnotetext{
${ }^{86}$ Dan Caldwell, 'The Cuban missile affair and the American style of crisis management', Center for the Study of Soviet International Behavior, p. 11, <http://www.rand.org/content/dam/rand/pubs/notes/2005/N2943.pdf>, [accessed 16 Feb 2018].

${ }^{87}$ Papers of Robert F. Kennedy. Attorney General Papers. Attorney General's Confidential File. 6-7: Cuba: Cuban Crisis, 1962: State Department (2 of 3 folders) (emphasis in original).

${ }^{88}$ White, The Kennedys and Cuba, p. 190.
} 
though at the beginning there was a much sharper division. ${ }^{89}$ It certainly convinced CIA Director McCone. When RFK reiterated this compromise approach the following morning, McCone agreed. Secretary of the Treasury Douglas Dillon also attributed RFK for persuading him to drop his support of the air strike but credited his 'intense but quiet passion' and the force of the Pearl Harbor analogy he made. ${ }^{90}$ This analogy was to liken America's possible strike on Cuba, which would precede any Cuban or Soviet attack on the US, to Japan's bombing of Pearl Harbor in 1941. RFK argued that such a strike, without warning, would not be 'the kind of country we are' and be 'a hell of a burden to carry.' 91

Yet one wonders whether to Dillon, a former air strike advocate, the notion from RFK of a compromise scenario, with more forceful measures still available, wasn't just as crucial as the moral argument encapsulated in the Pearl Harbor analogy. Likewise, Bundy must have been moved in part by a shared language of resolve. ${ }^{92}$ To the 'doves' within EXCOMM, RFK's passionate urging of the blockade route must have reassured them of a shared sensibility and like-minded caution. In short, RFK represented a 'middle-way' figure able to empathise with both blocs, backed with the aura of being the President's brother, suspected to reflect JFK's own preferred course of action.

\footnotetext{
${ }^{89}$ John F. Kennedy, 'After Two Years: a Conversation With the President'. In a memorandum for the President on October $20^{\text {th }}$ Sorensen also highlighted the advantage of the blockade as a 'flexible step...enabl(ing) us to move to an air strike... at any time it proves necessary'. Sorensen, Counselor, p. 399.

${ }^{90}$ Hilty, Robert Kennedy, p. 446.

${ }^{91}$ Ibid.,

${ }^{92}$ RFK even astutely mimicked Bundy's own phrasing in advocating the blockade route. Bundy 'favored decisive action'; RFK also ‘favored action'. In White, The Kennedys and Cuba, pp. 184-185.
} 


\section{iii. 'The Trollope Ploy'}

As with the blockade option, there appear two seemingly irreconcilable perspectives on RFK's role in what has been dubbed 'The Trollope Ploy', President Kennedy's strategy for navigating two very different proposals from Khrushchev on the evening of October 26th and the morning of October 27th, the former conciliatory and essentially requiring a simple promise not to invade Cuba and the latter announced publicly and calling for the removal of American Jupiter missiles from Turkey. ${ }^{93}$ The strategy was to accept Khrushchev's first proposal while barely acknowledging receipt of the second. Early historiography extolled the ploy as a clever ruse by $\mathrm{RFK}^{94}$, while later revisionism has revealed other advisors to have been just as responsible.

In reviewing the primary source material, it is certainly clear that RFK was not the first to touch on the beginnings of this stratagem. Bundy made the first suggestion, advocating the President reply saying, 'I would prefer to deal with...your interesting proposals of last night., ${ }^{95}$ RFK effectively took this suggestion forward when he later advocated intentionally ignoring the second proposal. Somewhat oddly, however, Bundy disagreed with RFK's revised approach of his own suggestion calling it 'too complicated.' 96 This is important. It is also important that the

\footnotetext{
${ }^{93}$ The Trollope ploy is a reference to a plot device by novelist Anthony Trollope, 'in which a woman interprets a pro-forma romantic gesture as a proposal of marriage.' In Ernest R. May and Philip D Zelikow (ed.), The Presidential Recordings: John F. Kennedy. The Great Crises, vol. 2, (New York, 2001), p. 213

${ }^{94}$ See Arthur Schlesinger Jr. A Thousand Days: John F. Kennedy in the White House, (New York, 1965), 828

${ }^{95}$ May and Zelikow (ed.), The Kennedy Tapes, p. 306.

${ }^{96}$ Ibid., p. 316.
} 
President at one point impatiently interrupted Ted Sorensen's presentation of the 'Trollope' stratagem, worried that they would just be 'screwing around for another 48 hours. ${ }^{\text {, } 97}$ At this stage it would appear the idea was gaining little ground, with its initial proponent seemingly abandoning it and the key decision-maker entirely dismissive of it.

It is here where RFK's indispensable role becomes clear, for debates on who did or did not conceive the Trollope ploy are a distraction. Far more interesting are Sorensen and Bundy's comments: respectively, 'Bobby's formula'98 and 'Bobby's notion' 99 . Both men were in the room for the preceding conversation, yet for some reason they still felt it important, in finally endorsing the Trollope ploy, to qualify it as 'Bobby's idea' - even Bundy, who had technically first broached it. This reveals two important aspects to RFK's role in the crisis. First, that whether he conceived the ideas or not, his voice was one that counted - and it invariably became recognised as the predominant one. The second aspect revealed is that RFK's voice was seen as an influential factor in influencing the President - supporting the view of RFK's essential role as privileged personal confidant. It is borne out in the final resolution of the response to Khrushchev, with RFK directly taking on the drafting with Ted Sorensen and chiding the President to let them 'try to work it out for you without you being there to pick it apart ${ }^{\text {'100 }}$ and the President eventually conceding 'we can try this thing.' 101

\footnotetext{
${ }^{97}$ Ibid., p. 347.

${ }^{98}$ Ibid., p. 350.

${ }^{99}$ Ibid., p. 351.

${ }^{100}$ Ibid., p. 350.

${ }^{101}$ Ibid., p. 351.
} 


\section{RFK as de-facto Chief of Staff, Presidential Agent and Intermediary}

Three roles taken on by RFK during the crisis - that of de-facto Chief of Staff, Presidential agent and intermediary - came together in one shared purpose in these thirteen days, that RFK be 'an instrument of his brother's ideas and intentions' ${ }^{102}$. Through this element of RFK's contribution, we again see the unique value RFK was able to bring to the President through their brotherly intimacy. The nature of the brothers' family bond is invariably pushed to the margins of studies on the crisis, but it is essential in understanding the full extent of RFK's contribution to the President during the crisis, and why this was indispensable in its successful resolution. It afforded the President a trust in RFK that he simply could not give to other advisors, and which therefore placed RFK in unique positions.

Throughout the Cuban Missile Crisis, RFK loomed large in the deliberations of President Kennedy's advisors, a first among equals. As one historian noted, 'Robert's strength lay in his ability to organise others to help his brother.' ${ }^{103}$ RFK's ability to aggregate the ideas of others, to uplift those he deemed significant, and to corral a disparate and varied group, was essential in enabling President Kennedy's successful management of the crisis. His legal training was no doubt advantageous, providing those skills of synthesis and advocacy that enabled him to brief his brother in the quick asides they shared throughout the crisis - some of which we have a record for, others we can only surmise. ${ }^{104}$ As Vice-President Johnson bitterly noted, 'Every

\footnotetext{
${ }^{102}$ Dallek, Camelot's Court, p. 423.

${ }^{103}$ Hilty, Robert Kennedy, p. 407.

${ }^{104}$ Consider that RFK was tasked with calling the President back from his campaign visits (see Sorensen, Kennedy, p. 1171) and must have had to brief him on EXCOMM disagreements when calling to secure his early return (see
} 
time they have a conference, don't kid anybody about who is the top advisor... Bobby is first in, last out. And Bobby is the boy he listens to. ${ }^{, 05}$ When questioned as to why RFK was afforded such preferment, President Kennedy replied: 'He has this terrific executive energy. We've got more guys around here with ideas. The problem is to get things done. Bobby's the best organiser I've ever seen.' 106

This organising contribution from RFK was essential. When Dean Acheson called EXCOMM a 'leaderless, inhibited group' ${ }^{107}$ he unwittingly conferred on this body its most perceptive compliment. With many meetings taking place without the President, participants could speak freely and openly, uninhibited. This helped the administration avoid the tacit consensus that proved so damaging in the Bay of Pigs operation and silenced frank assessments of that plan's viability. But it also presented a challenge to ensure meaningful output. RFK became the means of giving structure and direction to such free discussions, through 'constant prodding, questioning, eliciting arguments and alternatives and keeping the discussions concrete and moving ahead. ${ }^{108}$ He took on a clear leadership role when the President was absent, at times

\footnotetext{
May and Zelikow (ed.), The Kennedy Tapes, p. 125); we know he also briefed the President privately while he swam in the White House pool on the morning of October $20^{\text {th }}$ (Thomas, Robert Kennedy: His Life, p. 220); witness also the private conversation on the evening of October $23^{\text {rd }}$ for which we do have a record and which is highly revealing of their shared language (May and Zelikow (ed.), The Kennedy Tapes, pp. 219-222).

${ }^{105}$ Hilty, Robert Kennedy, p. 409.

${ }^{106}$ Ben C. Bradlee, Conversations with Kennedy, (New York, Kindle edn, 2014), p. 146.

107 James Chase, Acheson: The Secretary of State Who Created the American World, (New York, Kindle edn, 2007), p. 654.

${ }^{108}$ Sorensen, Kennedy, p. 1148.
} 
even convening them himself. ${ }^{109}$ As Bundy would later recall, 'wherever he sat was one of the most important places in the room. ${ }^{110}$ This is not surprising when we look at similar moments from before the Cuban Missile Crisis. A memorandum of an April 1961 post-Bay of Pigs meeting, where some thirty-five people were present, recalls RFK '(taking) the lead as at the previous meeting.' 111 This, too, in a meeting where the President himself was present and yet 'limited himself largely to asking questions.' 112 This leadership was apparent during the crisis too: it was RFK who takes the lead in summarising the alternatives, as noted by CIA Director McCone: 'At the conclusion of the meetings, which served the purpose of airing the views of all parties responsible for giving advice to the President, the alternatives open to us were summarized by the Attorney General. ${ }^{, 13}$ The dynamic is quite clear: with RFK assigned as his proxy, albeit a more forceful one, the President could maintain the objective distance his high office, and final decision-maker role, required - whether he was in the meeting or out of it.

In addition to such organising capabilities, RFK became the channel to refer these discussions back to the President. As Acheson remarked: the chief advice reaching the President throughout

\footnotetext{
${ }^{109}$ Sorensen records RFK 'conven(ing) the ExComm' on the afternoon of October 19 ${ }^{\text {th }}$. Sorensen, Counselor, p. 396.

${ }^{110}$ Thomas, Robert Kennedy, p. 214.

${ }^{111}$ White, The Kennedys and Cuba, p. 43.

${ }^{112}$ Ibid., p. 44.

113 John McCone, 'Memo for the Record', 17 October 1962, in FRUS, Cuban Missile Crisis and Aftermath (Foreign Relations of the United States, 1961-1963, Volume XI, Office of the Historian, Bureau of Public Affairs, United States Department of State.
} 
the crisis 'came to him through his brother.' ${ }^{\text {'14 }}$ This observation takes on even greater weight when we consider that, during the crisis, Acheson was 'Robert Kennedy's most forceful antagonist. ${ }^{115}$ The President did not work with a Chief of Staff - the role did not exist in Kennedy's administration ${ }^{116}$. Such a President, absent either an official or de-facto Chief of Staff, would have had to rely on memoranda or those departmental leaders that, as we have seen, carried particular objectives of their own. As it was, with RFK acting as de-facto Chief of Staff he could convey the views of others that did not make the formal record or did so but with insufficient force and needed drawing out. Indeed, on October $18^{\text {th }}$, as momentum toward the blockade option built, RFK proclaimed to a reduced group of advisors, 'I think George Ball has a hell of a good point' to which the President responded, 'What?'117 RFK then outlined the famous 'Pearl Harbor' argument: that for America to strike Cuba with no warning would not be 'the kind of country we are' and be 'a hell of a burden to carry.' ${ }^{118}$ Ball and others ${ }^{119}$ had raised these parallels earlier, yet it was only RFK's amplification of them that finally reached the President's ears. Kenneth O'Donnell would later talk of the merits of being able to raise a problem through RFK that was 'too sensitive' to mention to JFK directly, whereas 'Bobby could always reach him. ${ }^{120}$ Whether in a group meeting such as EXCOMM, or in their private conversations brother-to-brother, RFK's intimate relationship with the President gave him the confidence to expound arguments with unqualified vigour, where his more tentative

\footnotetext{
${ }^{114}$ Chase, Acheson: The Secretary of State Who Created the American World, p. 654.

115 Ibid.

${ }^{116}$ May and Zelikow (ed.), The Kennedy Tapes, p. 442.

${ }^{117}$ May and Zelikow (ed.), The Kennedy Tapes, p. 96.

118 Ibid.,

${ }^{119}$ Including CIA Deputy Director Marshall S. Carter on $16^{\text {th }}$ October in May and Zelikow (ed.), The Kennedy Tapes, p. 71.

${ }^{120}$ Kenneth P. O'Donnell and David F. Powers, Johnny, We Hardly Knew Ye, (Boston, 1972), p. 277.
} 
colleagues in EXCOMM felt obliged to do so gently, hedging the force of their argument uncertain as they were of the President's approval.

We know that RFK's use of this capability had an impact on the President. To return to Dean Acheson's recollections of the crisis, the former Secretary of State professed to have been appalled when the President used the phrase 'Pearl Harbor in reverse' in a private conversation between them, remarking to the President, 'I know where you got that ... it is unworthy of you to talk that way.' 121 In Acheson's remarks we see a contemporary's conviction that it was RFK, and not George Ball, who had imbued the President with the influential Pearl Harbor argument, but also one EXCOMM advisor's withering dismissal of the argument. It is no wonder that Ball was circumspect in advocating the argument amongst such colleagues; the President was fortunate that RFK was infinitely less so. In a similar vein, Hilty observed of RFK's role in the Trollope Ploy not that it was his own ingenious conceit but that 'Robert Kennedy summarized and presented in a convincing and cogent manner what others in the room...were in one way or another also suggesting. ${ }^{122}$ His role in the blockade argument was similar. McNamara may have been the first to propose the blockade route as a possible course of action on the second day of the crisis, yet as we have seen he still '(didn't) want to argue for this. ${ }^{123}$ It was RFK's amplification of McNamara's proposal later which was so pivotal. Such is the role of the principal advisor and de-facto Chief of Staff.

\footnotetext{
${ }^{121}$ Quoted in Reeves, President Kennedy: Profile of Power, pp. 584-585. Reeves subsequently analyses where JFK derived the phrase and where Dean Acheson thought he had, with Reeves concluding: 'The President was indeed getting it from his brother. More than once.'

${ }^{122}$ Hilty, Robert Kennedy, p. 449.

${ }^{123}$ May and Zelikow (ed.), The Kennedy Tapes, pp. 58-60 and p. 71.
} 
This principal role was not always one of supporting the other EXCOMM advisors. It was essential that the administration present a consensus to the world once a decision was made, to present a united front to the Soviets with no weakness to probe and exploit. JFK was no doubt aware of RFK's harsh exchange with the dissenting Under Secretary of State Chester Bowles in the aftermath of the Bay of Pigs, when 'an indignant RFK' told him that 'his position had henceforth better be that he was for invasion. ${ }^{124} \mathrm{He}$ knew what qualities he was calling on when he asked Sorensen and RFK on October $19^{\text {th }}$ to 'pull this thing together...it's falling apart.' ${ }^{125}$ For JFK knew that otherwise 'delays and dissension would plague whatever decision he took. ${ }^{126}$ RFK duly fulfilled this role, leveraging his well-known bond with the President to drive consensus. One can feel this in the highly suggestive memorandum for a key EXCOMM meeting on October $19^{\text {th }}$, where Bundy and Acheson argued forcefully for the strike option. Here, in response to Bundy declaring that he had spoken with the President that morning and was as a result now doubting 'whether the strategy group was serving the President as well as it might', RFK 'said with a grin that he too had had a talk with the President...He thought it would be very, very difficult indeed for the President if the decision were to be for an air strike...' 127 He went on to conclude the meeting in a decidedly final fashion: 'The Attorney General...made clear that he firmly favoured blockade...other steps subsequently were not

\footnotetext{
${ }^{124}$ Jacqueline Kennedy, Historic Conversations on Life with John F. Kennedy, (New York, Kindle edn, 2011), p. 505.

${ }^{125}$ Sorensen, Counselor, p. 396.

${ }^{126}$ Sorensen, Kennedy, p. 1171.

${ }^{127}$ Foreign Relations of the United States, 1961-1963, Volume XI, Cuban Missile Crisis and Aftermath, eds. Edward C. Keefer, Charles S. Sampson and Louis J. Smith (Washington: Government Printing Office, 1996), Document 31.
} 
precluded and could be considered; he thought it was now pretty clear what the decision should be. ${ }^{128}$

The tone clearly brooked no further argument, emphasising that the strike remained on the table as a future action and transposing his own conclusion onto the EXCOMM as a whole. Such forcefulness was not always popular. Indeed, another suggestive memo is that of Leonard Meeker, a legal advisor to the State Department during the crisis. In what is ostensibly a record of key aspects of the meeting, Meeker is at pains to include a telling exchange: 'Secretary Rusk then said he thought there should be an exposition of the legal framework surrounding possible military measures by the United States, turned to me, and seemed about to call on me, when the Attorney General signalled and said "Mr. Katzenbach.' After the meeting had finished, Meeker noted: 'On leaving the room, he (RFK) said to Mr. Katzenbach, half humorously: "Remember now, you're working for me.", ${ }^{129}$ RFK was clearly pushing for his own man's legal judgment to take precedent, and Meeker clearly wanted the reader to note this. But we must remember that President Kennedy had no Chief of Staff. Indeed, historians have criticised Bundy, the closest on paper to this role during the crisis, for failing to adequately prepare JFK for the EXCOMM meetings. ${ }^{130}$ Without such support, or the Chief of Staff role JFK eschewed from the outset of his Presidency, in such large and complex meetings this ability of his brother to support his objectives must have been indispensable. In short, as McNamara noted, RFK's

\footnotetext{
${ }^{128}$ Ibid..

${ }^{129}$ Leonard C. Meeker, 'Record of Meeting', 19 $9^{\text {th }}$ October 1962 in FRUS, Cuban Missile Crisis and Aftermath (Foreign Relations of the United States, 1961-1963, Volume XI, Office of the Historian, Bureau of Public Affairs, United States Department of State.

${ }^{130}$ May and Zelikow (ed.), The Kennedy Tapes, p. 442.
} 
skilful assumption of this de-facto Chief of Staff role was a reflection of 'his understanding of the lack of organization within the government to handle such an assignment.'131

Hilty has observed, 'Robert Kennedy did and said things the president could not, tested the water in places the president could not step and served as his eyes and ears in councils where the president could not go. ${ }^{132}$ We have already seen an example of RFK's role as JFK's eyes and ears in the Mongoose meeting on the first day of the crisis, taking forward JFK's request for invasion options. Yet he also acted as the President's agent, saying things the President could not, conscious as JFK was that the President must reserve judgment so as not to lead discussions. Robert Dallek has observed the two seemingly irreconcilable qualities here - RFK both being able to 'freely state his brother's views' and 'openly announce that he was declaring what the president wanted to be done.' ${ }^{133}$ Indeed, Richard Goodwin once observed RFK vehemently berating a collection of presidential advisors in the aftermath of Bay of Pigs, perceptively observing that, 'Bobby's harsh polemic reflected the president's own concealed emotions, privately communicated in some earlier, intimate conversation.' 134

An excellent example of this during the Cuban Missile Crisis can be found in a whispered aside between the two brothers, with JFK nudging RFK to press CIA Director John McCone on the timing of the discovery of the missiles:

\footnotetext{
${ }^{131}$ Hilty, Robert Kennedy, p. 408.

132 Ibid., p. 406.

${ }^{133}$ Dallek, Camelot's Court, p. 423.

134 Thomas, Robert Kennedy, p. 123.
} 
Robert Kennedy: [as a quieter aside] Should I go now?

President Kennedy: Yeah, you might as well get that over with because I think we'll probably need John McCone, who's got [unclear]...

Robert Kennedy: The question that I've heard raised rather extensively is why this was not uncovered sooner... why we didn't know about it... ${ }^{135}$

JFK was anxious to ensure one voice from his administration as to how and when the missiles were discovered, and the protocols that were in place (such as U2 overflights) to identify this at the earliest opportunity. McCone had given JFK cause to doubt that the administration had done all it could, and that there had been no oversights, so JFK wanted this probed further.

Just as the President used his brother as an agent for himself, so too was this role recognised by his wider group of advisors, in and out of EXCOMM, and called upon as required. Former Ambassador to the Soviet Union, Averell Harriman, wrote a memo to RFK on the morning of October $20^{\text {th }}$ writing of his own experience of profound Soviet discomfort at the 'encirclement' they felt the missiles in Turkey represented. ${ }^{136}$ Later that week RFK conveyed a confidential assurance of their removal on behalf of his brother. An additional example came later that evening when the President had essentially made the crucial decision for blockade. CIA Director McCone recorded in his Memorandum for the File, 20 October 1962: 'I spoke privately to the Attorney General. The Attorney General was to meet alone with the President,

\footnotetext{
${ }^{135}$ In Ernest R. May and Philip D Zelikow (ed.), The Presidential Recordings: John F. Kennedy. The Great Crises, vol. 2, (New York, 2001), p. 103-104.

136 Thomas, Robert Kennedy, p. 221.
} 
presumably to discuss policy matters. ${ }^{, 137}$ In this private meeting with RFK, McCone proceeded to outline his concerns about the course of action chosen. RFK followed this up with a call later that evening, saying that 'he had discussed my views with the President... and he felt (McCone) could rest assured.' ${ }^{138}$ The conversation then ended with RFK asking McCone to call the President later that evening. ${ }^{139}$ Nor was McCone an exception by virtue of the close working relationship the two men had built up through Operation Mongoose. For example, RFK knew of the value the President ascribed to McNamara and Thompson: 'Thompson he thought was outstanding...He made a major difference. The most valuable people during the Cuban crisis were Bob McNamara and Tommy Thompson. ${ }^{140}$ Knowing the President's respect for these two advisors, and with his own high opinion of them, RFK proactively sought to elicit their opinions as the crisis unfolded. We have seen earlier a moment in an October $25^{\text {th }}$ EXCOMM meeting where RFK explicitly called for Thompson's opinion, prodding JFK to follow suit. ${ }^{141}$ McCone's 20 October memorandum encapsulates RFK's interactions with all these advisors and is a rich vein of instruction. It reveals several central aspects to RFK's role in the crisis: firstly, advisors with concerns that they had felt unable to air in the central meetings, or that required more emphasis, would approach RFK, confident that it would be shared with JFK directly; secondly, RFK duly did raise those concerns with the President and had the unfettered access to be able to arrange private meetings or calls quickly to do so; thirdly, the President

\footnotetext{
137 John A. McCone, 'Memorandum for the Files', Central Intelligence Agency, DCI/McCone Files, Job 80B01285A, Meetings with the President, 20 October 1962.

138 Ibid.

${ }^{139}$ Ibid.

${ }^{140}$ Edwin O. Guthman and Jeffrey Shulman (ed), Robert Kennedy: In His Own Words, (New York, 1988), p. 420 .

${ }^{141}$ May and Zelikow (ed.), The Kennedy Tapes, p. 262.
} 
subsequently used RFK as a conduit to relay a reply to these advisors or, possibly on RFK's advice, would arrange a direct conversation; and fourthly, this channel put RFK at the centre of the information flow, invariably positioning him as the most knowledgeable man in the room - a de-facto Chief of Staff to the President. ${ }^{142}$

To this role, we must add RFK's relentless pursuit of the detail on behalf of his brother. RFK's personal files on the crisis, declassified in 2012 , hold as many as 3,584 documents directly reviewed by him. ${ }^{143}$ This assiduousness bears all the hallmarks of Evan Thomas' assessment that, 'Kennedy would bore in on a problem, reading sheaves of documents and making pointed comments in his small, squiggly handwriting.' ${ }^{144}$ The declassified collection contains reams of detailed accounts remarkably faithful to the Tapes. They include, for example, one handwritten calculation as RFK divides 500 by $17 .{ }^{145}$ Is this perhaps a spontaneous calculation concerning the blockade? We know that the quarantine line was modified on October 24, 1962, to an arc 500 miles from Cape Maysi, Cuba. ${ }^{146}$ The figure 17 could refer to sailing speeds,

\footnotetext{
${ }^{142}$ In the 2012 declassified files RFK has a Memorandum from McCone expressly for his and the President's eyes only. Robert F. Kennedy, Declassified Cuban Missile Crisis Papers.

${ }^{143}$ Robert F. Kennedy, Declassified Cuban Missile Crisis Papers.

${ }^{144}$ Thomas, Robert Kennedy, p. 112.

${ }^{145}$ Robert F. Kennedy, Declassified Cuban Missile Crisis Papers. See also Robert F. Kennedy, 'File 6-2-7 Cuba Executive Committee Meetings', RFK Notes and Memos, 26 October 1962.

${ }^{146}$ Chief of Naval Operations, “The Naval Quarantine of Cuba, 1963," in CNO, box 10, Post 1946 Report File, Naval Historical Center; and Curtis A. Utz, Cordon of Steel: The U.S. Navy and the Cuban Missile Crisis (Washington DC: Naval Historical Center, 1993).Available here: https://jfk14thday.com/naval-quarantine-linecuban-missile-crisis/ [accessed 19 Aug 2018].
} 
perhaps. We cannot be sure, but the proactive pursuit of independently corroborated detail is extraordinary and validates Evan Thomas' assessment.

RFK's intertwined roles of de-facto Chief of Staff and Agent were indispensable to the President and his successful handling of the crisis. Consider the failings of President Johnson's Tuesday Lunch Group, which was composed of many of the same advisors as EXCOMM and built around a similar idea of frank discussion. Yet 'the Tuesday Lunch Group suppressed its criticism and doubt about U.S. involvement in Vietnam rather than lose favour with the President. ${ }^{147}$ RFK was the safety valve in 1962 sorely missing in Johnson's administration.

In a letter to Premier Khrushchev at the height of the crisis, President Kennedy spoke of his concern that "we both show prudence and do nothing to allow events to make the situation more difficult to control than it already is. ${ }^{148}$ Here we see President Kennedy's acute understanding of organisation failings, so insightfully studied in Graham Allison's 1971 analysis of the Cuban Missile Crisis, Essence of Decision. JFK was keenly aware of these failings throughout his administration, most strikingly after the failure of the Bay of Pigs. In an interview in late 1962, the President bemoaned the bureaucratic delays within governmental organisations, complaining that 'there are so many interests that are involved in any decision' and declaring his view that 'one of the functions of the President is to try to have it move with

\footnotetext{
${ }^{147}$ Margaret G Hermann and Joe D Hagan, ‘International Decision Making: Leadership Matters’, Foreign Policy, No. 110, (1998), p. 133.

${ }^{148}$ White, The Kennedys and Cuba, p. 210.
} 
more speed. Otherwise you can wait while the world collapses. ${ }^{\prime 49}$ In selecting RFK for the role of 'diplomatic intermediary' ${ }^{150}$ to Khrushchev, JFK sought to circumnavigate the sluggish and equivocating State Department before the world collapsed about him. In doing so he sent a conscious message to the Soviet Premier during the crisis: RFK was his direct, personal emissary. The Soviets were receiving. Khrushchev's own son-in-law, Alexei Adzhubei, had met with RFK earlier in the year as part of 'figures from the President's circle'. Adzhubei also had a friendly exchange with JFK during the visit, subsequently relayed to Khrushchev, in which Adzhubei raised RFK's 'No. 2 in Washington' moniker, to which JFK's response was that RFK was not just 2 but ' $3,4,5$ and 6. ' 151

Reviewing RFK's contribution in these meetings, one is immediately impressed by RFK's articulate manner, his own records substantiated in Dobrynin's detailed accounts. While the professional diplomat Dean Rusk appeared 'clearly in a state of nervous tension' in an early crisis meeting with Dobrynin ${ }^{152}$, RFK's adept handling of this channel, balancing indignation and resolve with measured conciliation, was the right approach at the right time. RFK's tendency to direct communication and heated exchanges worked well as an effective foil to the national course of action chosen which, while dramatic, was not the military strong-arm it could have been. Rusk's early crisis meeting with Dobrynin presents a telling contrast to RFK: the

\footnotetext{
${ }^{149}$ John F. Kennedy, 'After Two Years: a Conversation With the President'.

${ }^{150}$ White, The Kennedys and Cuba, p. 6.

${ }^{151}$ USSR, Memorandum, A. Adzhubei's Account of His Visit to Washington to the CC CPSU, March 12, 1962. (in original Russian with English translation) Available here: https://nsarchive2.gwu.edu/nsa/cuba_mis_cri/620312\%20Adzhubei\%27s\%20Account.pdf [accessed 27 Aug 2018]

${ }^{152}$ Dobrynin, In Confidence, p. 82.
} 
same offers were presented to the Soviets, yet with no apparent effect to resolving the crisis ${ }^{153}$. The distinction is surely in Dobrynin being able to communicate RFK's offers as the direct voice of the President, including worrying concerns of military pressures on the President. For his part, Dobrynin believed that RFK's words 'rather correctly reflected the tense mood inside the White House', including the idea that there were some, in particular the military, 'spoiling for a fight', concluding that the sober picture such ideas depicted was subsequently decisive in Moscow. ${ }^{154}$ Dobrynin had "no doubt that my report of this conversation turned the tide in Moscow. ${ }^{155}$

We know now that Khrushchev had already decided to make his final announcement of October $28^{\text {th }}$ before receiving Dobrynin's note on his meeting with RFK on the $27^{\text {th }}$. However, as Naftali notes of Khrushchev's earlier shift between his conciliatory letter of the $26^{\text {th }}$ and his public demand of the $27^{\text {th }}$, Khrushchev was 'ever the gambler' and having 'recalculat(ed) the odds of a US invasion...thought he could push Kennedy a little harder. ${ }^{, 156}$ With such precedent it is not outlandish to suggest that, for all that US military preparations had so clearly affected him on the morning of the $28^{\text {th }}$, he might not have reversed course without Dobrynin's record of the RFK meeting striking a cautious note on the odds of invasion, dissuading Khrushchev from recalculating the risks and potentially adding demands to his $28^{\text {th }}$ message. Certainly, when the record was read aloud to the Presidium of the Central Committee, Oleg Troyanovsky,

\footnotetext{
${ }^{153}$ Compiled for The Cuban Missile Crisis, 1962 Edited by Laurence Chang \& Peter Kornbluh (New York: The New Press, 1992, 1998) and available here https://nsarchive2.gwu.edu/nsa/cuba_mis_cri/chron.htm ${ }^{154}$ Ibid., p. 79.

${ }^{155}$ Dallek, Camelot's Court, p. 423.

${ }^{156}$ Timothy Naftali, 'The Malin Notes: Glimpses Inside the Kremlin during the Cuban Missile Crisis', Cold War International History Project Bulletin, Issue 17/18, p. 301.
} 
Khrushchev's special assistant for international affairs, recalled that it created 'a state of alarm. ${ }^{, 157}$ Indeed, Khrushchev himself would later call the arrival of the report from Dobrynin a 'culminating moment.' 158

\section{Conclusions}

Robert Dallek, in his assessment of the Cuban Missile Crisis, concluded that RFK 'was the president's closest confidant.' ${ }^{159}$ This personal, fraternal intimacy ties together both the advisory and de-facto Chief of Staff aspects to RFK's role outlined in this article. Whether conferring privately or during EXCOMM deliberations, the brothers appeared to have an uncanny empathy with one another. It was RFK and JFK, alone amongst the members of the EXCOMM, who consistently probed Russian responses to the administration's chosen courses of action, as illustrated in JFK's concerned aside to RFK after the blockade had been implemented, 'But as you say and I say on that, I mean, what is (Khrushchev) going to do?'160 In short, as a contemporary observed: 'when Jack Kennedy wanted to be alone in a room with just one man, that man was Bobby ... He wasn't just the President's number two man. Bobby was number one and one-half.' 161

157 Bruce J. Allyn, James G. Blight and David A. Welch (ed.), Back to the Brink: Proceedings of the Moscow Conference on the Cuban Missile Crisis. (Lanham, 1993), pp. 71-75.

${ }^{158}$ Nikita Khrushchev, Memoirs of Nikita Khrushchev: Volume 3, Statesman (1953-1964), (Pennsylvania, Kindle edn, 2007), p. 338.

${ }^{159}$ Dallek, Camelot's Court: Inside the Kennedy White House, p. 423.

${ }^{160}$ May and Zelikow (ed.), The Kennedy Tapes, p. 221.

${ }^{161}$ Democratic national chair John M. Bailey quoted in Hilty, Robert Kennedy, p. 409. 
This was a relationship their father would have recognised, and indeed sought to enable early on in JFK's Presidency, but most importantly it was a dynamic that JFK knew he needed himself. As he said to RFK on appointing him as Attorney General, he needed someone who would tell him 'the unvarnished truth, no matter what,' ${ }^{162}$ to be his 'all-purpose consigliere.' 163 Constrained as we are by the evidence available, rich as it is, a picture nonetheless emerges of RFK as a 'confidant without agenda', an advisor not bound by departmental prejudice, but one seeking primarily to guide his President and his brother to a successful resolution of the crisis at hand. It is telling that a handwritten note made by RFK on October $16^{\text {th }}$, which splits the Hawks and the Doves in two columns, does not list himself. ${ }^{164}$ RFK considered himself apart from the other advisors, an agent of JFK's objectives.

Stern also writes of RFK as the President's 'most trusted advisor and confidant', observing a unique 'loyalty and trust' and recalling, from early hearings of the Tapes, 'their intuitive capacity to communicate. ${ }^{165}$ However, directly disagreeing with Sorensen's assessment that RFK 'never stat(ed) a position of his own', Stern argues that RFK 'staked out his own very provocative positions from the very first day.' ${ }^{166}$ YetStern's critique of RFK as being driven by a very personal, provocative agenda is not an image of RFK that President Kennedy would recognise. We smile wryly at JFK's famous riposte to General Le May's 'you're in a pretty

\footnotetext{
162 Thomas, Robert Kennedy, p. 110.

163 Ibid., p. 119.

${ }^{164}$ Robert F. Kennedy, Declassified Cuban Missile Crisis Papers.

${ }^{165}$ Stern, The Cuban Missile Crisis in American Memory, p. 40.

${ }^{166}$ Ibid., p. 42.
} 
bad fix ${ }^{167}$ aside, yet the President did have a keen awareness that the crisis ultimately was his responsibility. In RFK he had someone who had sat with him on a remote Pacific island while close to death. ${ }^{168} \mathrm{He}$ did not have merely an Attorney General. Indeed, in contrast to other department heads, the President's legal 'department head' dismissed concerns about the legal basis of the blockade saying 'that's all political; it's not legal.' ${ }^{169}$ In doing so RFK had analysed the crisis from his brother's office, with his brother's concerns. Behind this was that deep fraternal empathy, the shared outlook, and an overriding willingness for RFK to make his own objectives subservient to that of his brother.

It is hard to envisage anyone being more attuned to the President as RFK was to JFK during the crisis. Averell Harriman, Undersecretary of State for Political Affairs described RFK's 'value (as being) in his most extraordinary loyalty, his understanding of his brother's objectives, and his fierce instinct to protect him in every way he knew.' ${ }^{170}$ The most striking vindication of the indispensable nature of RFK's personal advice to President Kennedy can be seen in their dynamic after the Cuban Missile Crisis. If the Bay of Pigs demonstrated to JFK the role his brother could play, and the role he needed him to play, then the Cuban Missile Crisis was a vindication of that judgment. In a telephone conversation on 2 March 1963, the President actively sought his brother's advice on the Stennis Committee's review of the Bay of Pigs Invasion. One is struck by the deference accorded RFK by the President in this call, its culmination in the simple question: "What other ways do you have...how would you handle

\footnotetext{
${ }^{167}$ May and Zelikow (ed.), The Kennedy Tapes, p. 117.

168 Thomas, Robert Kennedy, p. 71.

${ }^{169}$ White, The Kennedys and Cuba, p. 185.

${ }^{170}$ Hilty, Robert Kennedy, p. 408.
} 
it?' ${ }^{171}$ This exchange not only underscores an indispensable partnership, forged in the crucible of nuclear crisis, but also hints at a dynamic during the crisis itself. Was this the dynamic between JFK and RFK in the private discussions and asides which, as noted earlier, we know occurred but do not have a record for ${ }^{172}$ Certainly, observers at the time inferred so. Here is one such observer commenting on RFK and JFK's private walks on the White House lawn during the crisis: 'They would have a discussion - the President would come back and join the group and that would indicate a particular decision or judgment that he made.' ${ }^{173}$

To return to RFK's confident advocacy of the blockade route, this was no doubt imbued by an intuition that the course would ultimately be favoured by his brother. It is likely this was confirmed by previous, privately held discussions. This confidence was an indispensable support to the President's burden of decision. No other advisor gave him such confidence. One can almost hear the President's private frustrations in an interview given by his wife Jackie in 1964: 'Bundy in the missile crisis, when you think of that great mind, in the beginning he wanted to go in and bomb Cuba. And at the end, he wanted to do nothing. So, if you'd been relying on that great intelligence, look where we'd be? ${ }^{174}$ Of course, Jackie Kennedy could have picked up such frustrations from myriad other sources, all potentially prejudiced, including her brother-in-law, RFK. However, when taken amongst the many other musings in

${ }^{171}$ John F. Kennedy, 'Stennis Committee Review of Bay of Pigs', Presidential Library: Telephone Recordings: Dictation Belt 8B. 1963.

${ }^{172}$ See Appendix I for the discussions we know took place.

${ }^{173}$ Edward A. McDermott, Director of the Office of Emergency Planning during the crisis, in White, The Cuban Missile Crisis, p. 160.

${ }^{174}$ Caroline Kennedy, Jacqueline Kennedy: Historic Conversations on Life With John F. Kennedy, (London, 2011), no page numbers. 
these interviews they are most probably informed by, as Michael Beschloss intimates in his introduction, 'what JFK and Jacqueline privately said to each other.' 175

RFK was indispensable because he was an invaluable partner to President Kennedy, an individual who bore the highest burden of decision-making. He 'allowed Kennedy to provide the sort of effective leadership that carried...the world to a peaceful resolution. ${ }^{176}$ But other forces, outside the control of either President Kennedy or Premier Khrushchev, also ensured the peaceful resolution of the crisis. Consider the case of Vasili Arkhipov, a senior officer on a Soviet submarine involved in the blockade confrontation who mercifully refused permission to launch its nuclear torpedo. ${ }^{177}$ Consider the outdated Jupiter missiles in Turkey and that they had not been withdrawn earlier, thus providing an 'escape hatch' during the crisis. ${ }^{178}$ It was fortunate, too, that the missiles were detected in mid-October before they were fully operational. These, and many other aspects besides, were indispensable factors in the peaceful resolution of the crisis.

They also infer some notable criticisms of RFK. One cannot salute RFK's foresight in forewarning of the missile emplacements, going against the grain of establishment thought, nor

\footnotetext{
175 Ibid.

${ }^{176}$ Dallek, Camelot's Court, p. 423.

${ }^{177}$ Edward Wilson, 'Thank you Vasili Arkhipov: the man who stopped nuclear war', The Guardian, 27 October 2012. <http://www.theguardian.com/commentisfree/2012/oct/27/vasili-arkhipov-stopped-nuclear-war> [accessed 17 Feb. 2018]

${ }^{178}$ Mark J. White, Missiles in Cuba Kennedy, Khrushchev, Castro and the 1962 Crisis, (Chicago, Kindle edn., 1997), p. 1957.
} 
his questioning of Cold War certainties, against the grain of his times, without asking why he did not go further. Consider the Jupiter missiles. In repeating his brother's frustrations on the matter, RFK complained at the time and in his memoir on the crisis that earlier directives to remove the Jupiter missiles in Turkey had not been implemented. Bernstein and others have since observed this to have been 'foolishly optimistic', given both the timing of such directives (as late as $23^{\text {rd }}$ August 1962) and their indirect manner. ${ }^{179}$ Yet whether disingenuous or naïve, RFK missed the point. These missiles became fundamental in resolving the crisis - far from being a hindrance, they were a helpful tool. Both RFK and his brother talked of Khrushchev's possible responses during the crisis, but they failed to see his need, matching their own, for a modicum of success in any resolution. The Jupiter missiles presented that opportunity. Far from bemoaning them, RFK should have been rejoicing at their usefulness. As Don Munton as observed, Soviet Foreign Minister, Andrei Gromyko, would repeatedly indicate - in the 1970s and again at the 1989 Moscow conference - that the Jupiter withdrawal was 'key to the crisis resolution.' ${ }^{180}$

However, whilst such considerations are undoubtedly important, ensuring we resist mythical heroic narratives of the past, fundamentally this was a crisis in which the wrong individuals, with the wrong advice, taking the wrong actions, could have easily tipped the world into nuclear war. That this did not happen was a testament to both President Kennedy and Premier Khrushchev. In this context, RFK really enabled President Kennedy to succeed - what Thomas calls this 'blending of their complementary talents, JFK steady and reasonable, RFK urgent

\footnotetext{
${ }^{179}$ Bernstein, 'The Cuban Missile Crisis: Trading the Jupiters in Turkey?', p. 103.

${ }^{180}$ Don Munton, The three puzzles: Essence of Decision and the missile crisis', in Len Scott and R. Gerald Hughes, eds., The Cuban Missile Crisis: A Critical Reappraisal. (London, 2015), p. 155.
} 
and probing. ${ }^{181} \mathrm{He}$ cut through the bureaucratic State Department in delivering urgent lines of negotiation to Khrushchev. He ensured all options were considered and considered with all the rigour that this unprecedented crisis demanded. He held the administration together in a united front, ever conscious of the need to show resolve to Khrushchev and the world. When he had resolved upon the right course of action, he advocated it courageously and with the utmost passion. On the last night of the crisis, we therefore cannot be surprised at JFK's aside to his friend Dave Powers, 'Thank God for Bobby.' 182

\footnotetext{
181 Thomas, Robert Kennedy, p. 233.

${ }^{182}$ Ibid.
} 